\title{
EVIDENCE-BASED PRACTICE TEACHING INTEGRATION IN COLLEGE NURSING STUDIES: HISTORICAL AND LEGAL ASPECTS
}

\author{
Danguolė Šakalytė \\ Mykolas Romeris University, Utena College, Lithuania \\ Valdonė Indrašienė \\ Mykolas Romeris University, Lithuania
}

\begin{abstract}
To better understand and analyze the education of evidence-based practice, it is necessary to review the context and premises of the formation of evidence-based practice itself. The beginning of the evidence-based practice movement in the teaching of health professionals' dates back to 1910 and looking at the health care system; first, there was evidence-based medicine. In 1990, Sackett's initiative at McMaster University in Canada, it was decided to change the term "evidence-based medicine" to "evidence-based practice" (Mackey \& Bassendowski, 2017; Thom \& Eaves, 2015). In nursing, the beginning of evidence-based practice is linked to the reforms of nursing science and practice by the first nursing researcher, Florence Nightingale, from 1854 to 1910, although the term of "evidence-based practice" was not yet known at the time. The professional training of nurses as one of the leading health professionals is related to health policy and the development of nursing science. The European Qualifications Framework (EHEA) defines the expected learning outcomes for professionals with a bachelor's degree, including the skills to find, evaluate, reflect, and apply scientific information in practice (Bologna Working Group, 2005). Despite international and national recommendations, it is difficult for many higher education institutions to refine the steps of teaching evidence-based practice in nursing study programs. These difficulties are revealed by the ambiguity in the definition of the concept of evidence-based practice (Horntvedt et al., 2018).
\end{abstract}

The problematic question is: What is the basis for integrating evidence-based practice training into college nursing study programs?

The study is based on the scientific literature review.

Keywords: evidence-based practice history; evidence-based practice; evidence-based practice teaching; nursing education.

\section{Introduction}

The world is in a period of rapid change characterized by technological and social progress. Whatever the scale of the system is, if it does not adjust to the changing environment, it is doomed to stagnation. This also applies to the higher education system: in order to achieve the quality of studies, it is necessary to take into acount the needs of the labor market and the guidelines of the European Union 
Šakalyte \& Indrašiene, 2021. Evidence-Based Practice Teaching Integration in College Nursing Studies: Historical and Legal Aspects

(Jović, Knežević, Skrobić, Matavulj, \& Vučković, 2015). Nursing education is one of the open systems that can only be viable by changing, depending on environmental challenges.

Given the ever-changing nature of health care, new ideas are being developed to improve patient care: new technologies are being introduced, more effective drugs are being discovered, treatment and nursing methods are being developed, and evidence-based practice is becoming increasingly valuable in nursing education (Kang, Kim, Kim, You, Choi \& Hwang, 2016; Wilson \& Klein, 2012).

Quality of nursing education organization also affects assimilation of evidence-based practice. As Lithuania moves to a higher level of training for nursing professionals, it is possible to see the current gap between theory and practice, which may widen further without taking action by reviewing the education of nurses themselves and the design of study programs. To avoid this gap, all evidence-based practice training steps must be included in nursing training programs as this is a key medium developing nursing students' professional knowledge, skills, and clinical approach (Lehane, Warren, O’Riordan, Savage, Drennan, O’Tuathaigh, Hegarty, 2017).

Evidence-based practice is one of the latest paradigms in nursing education. It is a nursing practice where nurses make decisions of clinical nursing based on the evidence of the research, the nurses' clinical experience, taking into account the patient's needs and wishes (Melnyk, Fineout-Overholt, Giggleman \& Cruz, 2010).

In countries with a deep tradition of nurse training, the education of evidence-based practice and its integration into curricula began a debate about it about two decades ago (Melnyk, Fineout-Overholt, Giggleman, \& Cruz, 2010; Larsen, Terkelsen, Carlsen, \& Kristensen, 2019) and in Lithuania, the education of nurses' evidence-based practice is an understudied field.

Despite the World Health Organization (Martins, Baptista, Coutinho, Fernandes \& Fernandes, 2018), recommendations of the International Clinical Simulation and Training Nursing Association (INACSL) (INACSL Standards Committee, 2016), description of the Lithuanian Nursing and Midwifery Study Field (2015), the provisions of Directive 2013/55/EU of the European Parliament and the Council and the Guidelines of the Lithuanian National Nursing Policy 2016-2025 (National Nursing Policy ..., 2016), refined evidence-based practice training steps in nursing study programs for many of the country's higher education institutions is difficult to achieve. These difficulties are revealed by the ambiguity in the definition of the concept of evidence-based practice (Horntvedt, Nordsteien, Fermann, \& Severinsson, 2018).

The problematic question of the article is: what is the basis for integrating evidence-based practice training into college nursing study programs? 


\section{Methodology of Investigation}

The literature review was planned and written in accordance with PRISMA (Prefered Reporting Item for Systematic Review and Meta-Analyses) requirements for the preparation of a systematic review. In order to answer the problematic question of the article - in 2020 February-June a targeted literature search was conducted in EBSCO and ScienceDirect databases. The following keywords were used for the first search: evidence-based practice history; evidence-based practice teaching; nursing education other similar terms. Scientific information was also collected by reviewing the bibliographies of articles selected for analysis, and by reviewing related or similar articles.

Articles were selected for analysis using the following selection criteria: 1) the scientific article was published in a peer-reviewed scientific journal; 2) full text article in English; 3) due period - articles published in 2000-2020; 4) the article analyzes the history of the development of evidence - based practice and the legal aspects of its integration into the study process.

To ensure the validity of the literature review of the scientific literature was: formulated criteria for inclusion and exclusion of publications; all scientific publications meeting the selection criteria are included in the list of analyzes and analyzed. Such criteria - the research methods used in the article, the country where the research took place - were not relevant for the selection. 15 out of 142 article were included in this review. Nine article that were included in the analysis were descriptive $(3 ; 6 ; 15 ; 17 ; 22 ; 26 ; 27 ; 28 ; 29)$, four used a quantitative research strategy $(19 ; 20 ; 23 ; 24)$, one for qualitative research $(2)$ and one for mixed research (11).

Articles selection process graphically illustrated in Figure 1.

The four-phased approach of Grove, Burns, \& Gray (2012) for reviewing literature is used: skimming, comprehension, analysis and synthesis of sources.

Skimming involves reading the titles, summary and keyword to decide which articles to include or exclude. The articles included are peer reviewed, original products that describe the history of the development of evidence-based practice and the legal aspects of its integration into the study process. The articles excluded are based on assessing the knowledge of nurses and nursing students about evidence-based practice. It is important to note that the literature review by the authors is limited to articles reviewing the reasons for the formation of evidencebased practice and to analyse the legal basis for the integration of evidence-based practice into nursing study programs. Comprehension takes place by critically reviewing the articles, understanding the content, taking notes about main themes. Analysis implies categorizing the articles in relation to the research question. The authors repeated this stage several times. The data articles are listed in Literature Summary Table in order to systematically review, analyze, summarize and 
Šakalytè \& Indrašiene, 2021. Evidence-Based Practice Teaching Integration in College Nursing Studies: Historical and Legal Aspects

interpret the obtained results. During the analysis of the material presented in the articles, the data of author and year, purpose, framework, results and findings were included. Synthesis of sources involved clarifying the mean of the information in oder to answer the research question.

In order to assess the legal basis for the application of evidence-based practice, international $(n=4)$ and national $(n=2)$ documents governing the teaching of evidence-based practice in nursing programs were analyzed.

The data obtained during the analysis are interpreted based on the ideas of B. M. Melnyk's (2011) evidence-based theory of nursing practice.

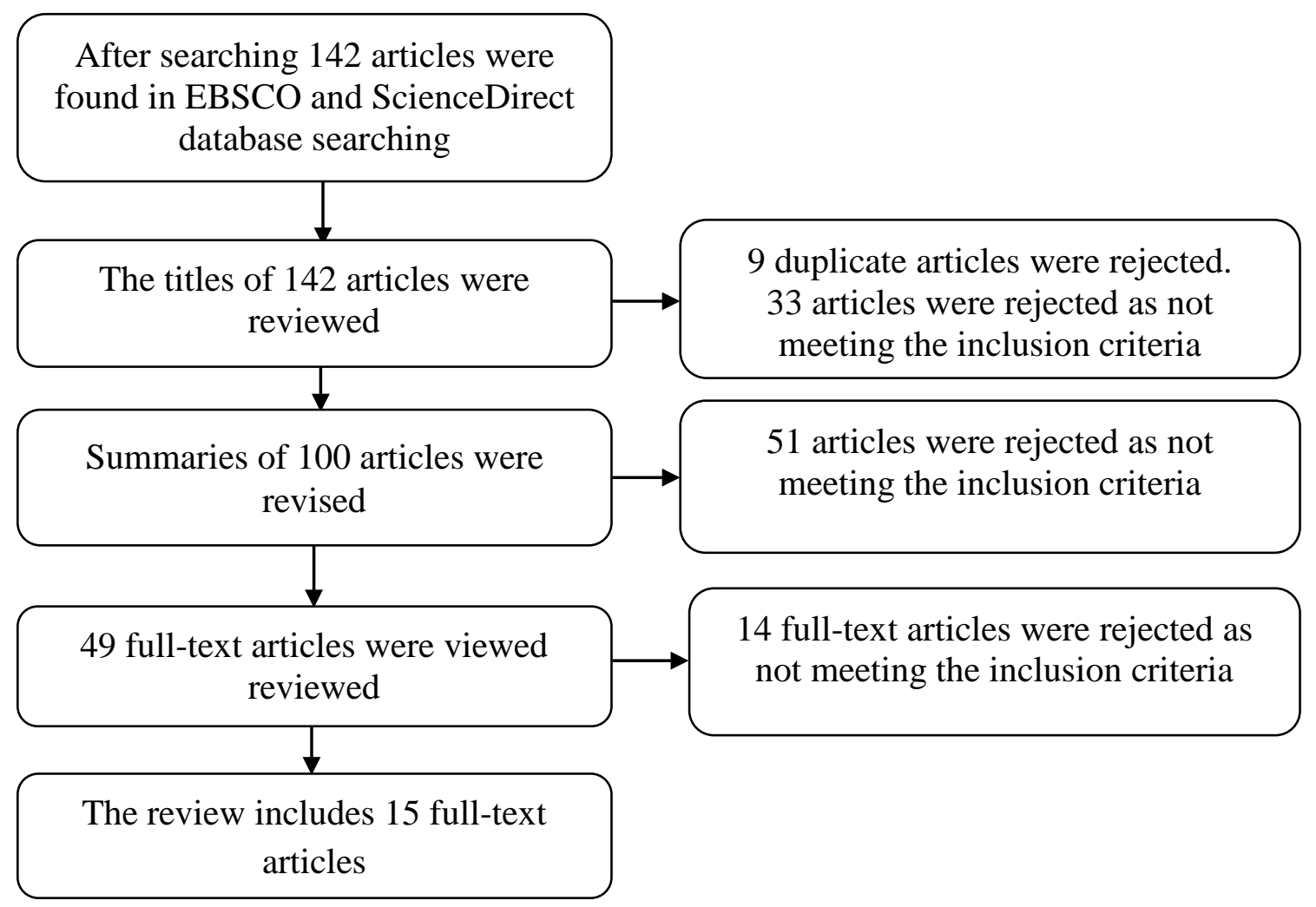

Figure 1 Articles Selection Process

\section{Research Results}

The main issues raised during the analysis of the articles are discussed below:

- $\quad$ The historical context of the formation of evidence-based practice;

- Legal basis for the integration of evidence-based practice teaching in nursing studies

\section{The historical context of the formation of evidence-based practice}

The beginning of the EBP movement in health care education dates back to 1910, when the North American Medical Association approached researcher 
Abraham Flexner with a request to investigate the quality of health care training in U.S. and Canadian medical schools. 155 medical schools were included in the study field (Steglitz, Warnick, Hoffman, Johnston, \& Spring, 2015). The results of the study showed that more than half of the medical schools participating in the study provided insufficient clinical training for specialists, and the education of the specialists themselves was not based on any scientific evidence. Based on a study conducted by A. Flexner (1912), he formulated a quality standard for the training of health care specialists, which many medical schools of the time did not implement in the study process. As a result, in 1935, more than half of all medical schools that participated in the study closed as unable to prepare practitioners. This study by Flexner is seen as the beginning of evidence-based practice in the education of health professionals as it has led to educational reform related to the training of these professionals in the United States and Canada (Steglitz et al., 2015).

Looking at the health care system first started talking about evidence-based medicine. The majority of the literature shows the beginning of evidence-based practice, originally known as evidence-based medicine, back to Archie Cohrane in the 1970s (Mackey \& Bassendowski, 2017). Until the dissemination of substantiated research publications, people believed that making decisions about patient care is an individual choice by the doctor. It was believed that each doctor thinks correctly and makes the right decisions (Melnyk, Fineout-Overholt, Giggleman, Cruz 2010). A. Cochrane 1972 argued that healthcare systems have limited resources and should therefore only use proven and effective treatments and that doctors' decisions about patients' treatment were unreasonable and based on the disease but not on the individual patient's case (Stavrou, Challoumas \& Dimitrakakis, 2014; Steglitz et al., 2015; Dawes, Summerskill, Glasziou, Cartabellotta, Martin, Hopayian, Osborne, 2005; Melnyk, Gallagher-Ford, Long et al., 2014).

Twenty years later, in 1992, funding for the Cochrane Center has been approved by the UK National Health Service; to facilitate the dissemination of the results of randomized surveys. 1993 center name was changed to Cochrane collaboration and brought together fifteen Cochrane collaboration centers on all continents. The activities of these centers cover all areas and specializations of medicine. Their common goal is to find and present the most reliable, scientifically proven facts for the treatment of specific diseases (Stavrou et al., 2014).

While A. Cochrane's researchers worked to evaluate the significance and importance of clinical research in evidence-based practice, Canadian researcher David Sackett analyzed the meaning of the concept itself. D. Sackett (1990) argued that the previous decision to link evidence-based practice only to the application of best treatment methods in clinical practice is wrong, and it does not 
Šakalytè \& Indrašiene, 2021. Evidence-Based Practice Teaching Integration in College Nursing Studies: Historical and Legal Aspects

reflect its deep meaning and purpose. This practice includes critical thinking by healthcare professionals, patient-centered clinical decisions, patient safety ensuring, and aspects of the emotional state of the patient and his/her loved ones. Therefore, in 1990, at the initiative of D. Sackett at McMaster University in Canada, it was decided to change the term "evidence-based medicine" to "evidence-based practice". Sackett, Rosenberg, Muir, Haynes \& Richardson (1996) defined its term as follows: "the conscientious, explicit and judicious use of current best evidence in making decisions about the care of individual patients" (as cited Mackey \& Bassendowski, 2017, p. 5). Scientists (Melnyk, 2012; Steglitz, 2015; Dawes, 2005) later analyzed the concept of evidence-based practice and argued that this description of evidence-based practice has changed insufficiently and is used to this day. As noted by A. Mackey \& S. Bassendowski (2017) this change seeks to ensure that evidence-based practice is used not only by physicians but also by nurse, psychologists, and all other health care professionals to achieve the common goal of a holistic approach to patient health, well-being and its improvement.

Thus, evidence-based practices have become more widely discussed on oder to improve the quality of services provided by healthcare specialists and to ensure the best possible health status for patients. However, this is not sufficient to explain the main processes of evidence-based practice and to distinguish the evidence-based process from the evidence-based outcome. It needs to be clearly defined: what the concept of evidence-based practice itself means, what evidencebased practice skills are required and what the curriculum should be, which sets out the necessary steps for education evidence-based practice (Dawes et al., 2005).

2003 in Evidence-Based Practice Conference "Signposting the future of EBHC" in Sicily, Italy, a communique was adopted. As mention Dawes (2005) in this communique stating that: „all health care professionals need to understand the principles of evidence-based practice in action, complement evidence-based policies, and have a critical attitude to their own practice and to evidence. The teaching of evidence-based practice should, as far as possible, be integrated into the clinical setting and routine care so that students not only learn the principles and skills, but learn how to incorporate these skills with their own life-long learning and patients care" (Dawes et al., 2005, p. 2).

Following the adoption of this communique a directive 2005/36/EU on the recognition of professional qualifications, which defines the educational requirements of doctors, nurses, and other regulated health care professionals, was prepared by the European Parliament and the Council in 2005 (Directive of the European Parliament and the Council..., 2005).

Evidence-based practice evolved from Florence Nightingale in 1854-1910 with her reforms in nursing science and practice, although at that time, the concept 
of "evidence-based practice" was not yet known. F. Nightingale applies this practice in her work to achieve the best possible results in the nursing process and to improve the education of nurses. She argued that there is a lack of knowledge of nursing theory in practice and professional nursing teachers in schools, nurses must learn from their practice by describing, analyzing each case of nursing, and submitting the analysis to the teacher (Selanders \& Crane, 2012).

With the development of nursing science worldwide, evidence-based practice has become its foundation. Since 1998 the magazine "Evidence-Based Nursing" began to be published for nurses and nursing students, containing main articles with expert comments, focusing on main conclusions of research and their impact on nursing practice. And in 2011 nursing researcher B. M. Melnyk formulated the concept of evidence-based practice in nursing: "evidence-based nursing practice should be a problem-solving approach to clinical practice that integrates a systenatic search for, and critical appraisal of the most relevant evidence to answer a burning clinical question. It should take into account, for example, one's own clinical expertise, patient preferences and values“ (Melnyk, 2012, p. 5). In later published studies C. J. Thompson (2016), H. Saunders et al. (2018) defined three main components of evidence-based nursing practice: best evidence, clinical experience, and patient preferences.

\section{Legal basis for the integration of evidence-based practice teaching in nursing studies}

The professional training of nurses as one of the main health care professionals is related to health care policy and the development of nursing science. The European Qualifications Framework for Higher Education (EHEA) defines the expected learning outcomes for professionals with a bachelor's degree, including the skills to find, evaluate, reflect, and apply scientific information in practice (Bologna Working Group, 2005). The International Code of Ethics for Nurses also emphasizes that nurses must know and apply research findings in their clinical practice (International Ciuncil of Nurses (ICN), 2012).

In 2013 a directive 2013/55/EU of the European Parliament and the Council is issued, which partly changes directive 2005/36/EU, and in which eight key professional competencies for nurses is defined, high lighting the need for training in evidence-based practice. The directive states that after completing nursing studies, the professional must independently identify the necessary care, plan, organize and carry out the care of treated patients to improve professional practice through the application of science-based general nursing knowledge and skills.

In 2015, in Lithuania, a description of the study field of Nursing and Midwifery is being prepared, which defines general and specific learning outcomes to be achieved by a graduate of the Nursing study program. The description of the field of study also highlights the acquisition of evidence-based 
Šakalyte \& Indrašiene, 2021. Evidence-Based Practice Teaching Integration in College Nursing Studies: Historical and Legal Aspects

practice skills. And the new Lithuanian National Nursing Policy Guidelines for 2016-2025 anticipates three priority directions of nursing development: improving the quality of care and patients safety, planning the need for nurses, and improving competencies and the impelementation of evidence-based solutions in nursing science (2016, p. 4). Considering these guidelines, the training of nurses must be based on the interaction between the nurses' practice, their teaching methods, and research.

The whole legal framework would seem to provide a basis for future nurses to acquire evidence-based practice skills. However, in 2019 at the initiative of the European Commission wide coverage research was conducted in order to assess changes of the general practice nurses education (it is one of the sectoral professions defined in directive 2005/36 /EU). This research appears that: "In Lithuania, the knowledge and skills acquired by a nurse and the subjects of study programs should be clearly linked to the professional competencies set out in the directive (Article 31 (7) of the Directive). There is not a clear definition of what the concepts "Evidence-Based Practice" and "research" mean. It is not sufficient to include "research knowledge". Evidence-Based Practice is much more than research; it is also the use of research in the practice, patients' needs, patients' perception, etc. (SARK. Workshop Feedback Report, 2019).

Why it is so substantial for nurses to learn to apply evidence-based practice? B. M. Melnyk, L. Gallagher-Ford, L. E. Long et al. (2014) specifies evidencebased practice nursing principals: "when performing nursing activities, nurses follow the best available evidence, clinical decisions based on science-based facts proven in clinical trials, the individuals needs of the patient are taken into account in the development of the nursing plan". And in applying traditional nursing practice, nurses are guided by the authority's opinion, personal knowledge and experience, and the traditions of performing nursing actions. However, not updated knowledge is rapidly aging, personal experience is limited, the views of authorities can vary, and traditions can also vary greatly from country to country and from institution to institution. If implementing evidence based practice nursing, the individual needs of the patient are taken into account, it is appling the same methods in traditional nursing even to patients with the same disease are inefficient (Melnyk et al., 2014). Nursing study program which content is based on the steps of the evidence based practice training gives the study program its uniqueness; emphasizes the effective development of student's knowledge and skills; improves clinical competencies, communication, and critical thinking skills; creates conditions for students to achieve a higher level of study results. (Cordeau, 2012; Edeer \& Sarikaya, 2015; Hung et al., 2019). 


\section{Conclusions}

Evidence-based practice is one of the paradigms of nursing education, focused on developing the ability of future professionals to make clinical decisions based on the best available research evidence, nursing clinical experience, taking into account the patient's wishes and needs.

The application of evidence-based practice in the nursing education is linked to the prioritization of the importance of clinical trials and the needs of patients to ensure bthe quality of services.

By discussing the concept of evidence-based practice from a historical perspective, we can clearly see the links between evidence-based practice and nursing education and practice. Teachers have every opportunity, regulated by law, to fully integrate and improve the teaching of evidence-based practice in nursing study programs. It is important that the training of nurses encourages commitment to evidence-based practice and the strengthening and maintenance of competence in lifelong learning.

\section{References}

Bologna Working Group. (2005). A Framework for Qualifications of the European Higher Education Area. Bologna Working Group Report on Qualifications Frameworks. Retrieved from http://ecahe.eu/w/index.php/Framework_for_Qualifications_of_the_ European_Higher_Education_Area

Cordeau, M. A. (2012). Linking the Transition: A Substantive Theory of High-stakes Clinical Simulation. Advanced in Nursing Science, 35(3), 90-102.

Dawes, M., Summerskill, W., Glasziou, P., Cartabellotta, A., Martin, J., Hopayian, K., .. Osborne J. (2005). Sicily statement on evidence-basedpractice. BMC Medical Education, 5(1). doi:10.1186/1472-6920-5-1

European Parliament and Council. (2005). Directive 2005/36/EC of the European Parliament and of the Council of 7 September 2005 on the recognition of professional qualifications. Retrieved from https://eur-lex.europa.eu/legal-content/EN/TXT/?uri= CELEX:32005L0036.

European Parliament and Council. (2005). Directive 2013/55/EU of European Parliament and of the Council of 20 November 2013 amending Directive 2005/36/EC on the recognition of professional qualifications. Retrieved from https://eur-lex.europa.eu/legal-content/ EN/TXT/?uri=CELEX:32013L0055.

Edeer, A. D., \& Sarikaya, A. (2015). The Use of Simulation in Nursing Education and Simulation Types. Journal of Education and Research in Nursing, 2(2), 121-126.

INACSL Standards Committee. (2016). INACSL Standards of Best Practice: Simulation ${ }^{\text {SM }}$ Facilitation. Clinical Simulation in Nursing, 12(S), 16-20. doi.org/10.1016/ j.ecns.2016.09.007.

International Council of Nurses (ICN). (2012). ICN code of ethics for nurses. Geneva: ICN. Retrieved from http://www.icn.ch/images/stories/documents/about/icncode_english.pdf.

Grove, S. K., Burns, N., Gray J. (2012). The Practice of Nursing Research: Appraisal, Synthesis, and Generation of Evidence. Elsevier Saunders, St. Louis, Mo. 
Šakalytė \& Indrašienè, 2021. Evidence-Based Practice Teaching Integration in College Nursing Studies: Historical and Legal Aspects

Jović D., Knežević, D, Skrobić, M. Matavulj, A. \& Vučković, J. (2015). Attitudes and opinions of health care students of Medical Faculty in Banja Luka about study program and nursing as a profession. Scripta Medica, 46(1), 49-54. doi: 10.7251/SMDEN1501049J.

Horntvedt, M-E. T., Nordsteien, A., Fermann, T. \& Severinsson, E. (2018). Strategies for teaching evidence-based practice in nursing education: a thematic literature review. BMC Medical Education, 18, 172. doi.org/10.1186/s12909-018-1278-z.

Hung, HY., Wang, YW., Feng, JY., Wang, C J., Lin, E.CL., \& Chang, Y J. (2019). EvidenceBased Practice Curiculum Development for Undergraduate Nursing Students: The Preliminary Results of an Action Research Study in Taiwan. The Journal of Nursing Research, 27(4),1-11. doi.org/10.1097/jnr.0000000000000298.

Kang, H. J., Kim, O., Kim, H. S., You, S. Y., Choi, S. O., \& Hwang, H. M. (2016). Effects of the Self-observation Method of Essential Fundamental Nursing Skills on Self-directed Learning Ability, Selfconfidence and Practice Satisfaction. Journal of Learner-centered Curriculum and Instruction, 6(9), 227-241.

Larsen, C. M., Terkelsen, A. S., Carlsen, A-M. F. \& Kristensen, H. K. (2019). Methods for Teaching Evidence-based Practice: a Scoping Review. BMC Medical Educational, 19, 259. doi.org/10.1186/s.12909-019-1681-0.

Lehane, E., Warren, P. L., O’Riordan, C., Savage, E., Drennan, J., O’Tuathaigh, C., ... Hegarty, J. (2017). Research on Teaching of Evidence Based Practice in Ireland - to Healthcare Professionals and Healthcare Students. Retrieved from https://health.gov.ie/wpcontent/uploads/2018/01/Teaching-of-EBP-in-Ireland- Summary-report-Oct2017.pdf.

Mackey, A. \& Bassendowski, S. (2017). The History of Evidence-Based Practice in Nursing Education and Practice. Journal Professional Nursing, 33(1), 1-55.

Martins, J. C. A., Baptista, R. C. N., Coutinho, V. R. D., Fernandes, M. I. D., \& Fernandes, A. M. (2018). Simulation in Nursing and Midwifery Education. Retrieved from https://www.euro.who.int/_data/assets/pdf_file/0011/383807/snme-reporteng.pdf?ua $=1$

Melnyk, B. M. (2012). Improving Quality of Care and Patient Outcomes with Evidence-based Practice and the ARCC Model. Retrieved from http://www.downstate.edu/ icl/rebp2012/BethMazurelMelnyk-ImprovingQualityofCareandPatientOutcomeswith Evidence-bas.pdf.

Melnyk, B. M. \& Fineout-Overholt, E. (2011). Evidence-based practice in nursing \& healthcare: a guide to best practice. 2nd ed. Wolters Kluwer Health Lippincott Williams \& Wilkins.

Melnyk, B. M, Fineout-Overholt, E., Giggleman, M., \& Cruz, R. (2010). Correlates among Cognitive Beliefs, EBP Implementation, Organizational Culture, Cohesion and Job Satisfaction in Evidence-Based Practice Mentors from a Community Hospital System. Nursing Outlook, 58(6), 18-30. doi:10.1016/j.outlook.2010.06.002.

Melnyk, B. M, Gallagher-Ford, L., Long, L. E. \& Fineout-Overholt, E. (2014). The Establishment of Evidence-Based Practice Competencies for Practicing Registred Nurses and Advanced Practice Nurses in Real-World Clinical Settings: Proficiencies to Improve Healthcare Quality Reliability, Patient Outcomes, and Costs. Worldviews Evidence Based Nursing, 11(1), 5-15.

Nacionalinés slaugos politikos 2016-2025 metu gairès. (2016). Patvirtinta Lietuvos Respublikos sveikatos apsaugos ministro $2016 \mathrm{~m}$. vasario $10 \mathrm{~d}$. isakymu $\mathrm{Nr}$. V-222. Retrieved from <https://e-seimas.lrs.lt/portal/legalAct/lt/TAD/f3e32e80d10211e 59019a599c5 cbd673? jfwid=-fxdp770g>. 
SARK. (2019). Workshop Feedback Report. EU minimum harmonised training for general care nurses - time for an update?

Saunders, H, Vehviläinen-Julkunen, K. (2018). Key considerations for selecting instruments when evaluating healthcare professionals' evidence-based practice competencies: A discussion paper. Journal Advancing Nursing, 74 (10), 2301-2311.

Selanders, L. C., Crane, P. C. (2012). The voice of Florence Nightingale on advocacy. Online Journal of Issues in Nursing, 17(1). doi:10.3912/OJIN.Vol17No01Man01.

Slaugos ir akušerijos studiju krypties aprašas. (2015).

Stavrou, A., Challoumas, D. \& Dimitrakakis, G. (2014). Archibald Cochrane (1909-1988): the father of evidence-based medicine. Interactive CardioVascular and Thoracic Surgery, 18(1), 121-124.

Steglitz, J., Warnick, J. L., Hoffman S. H., Johnston, W. \& Spring B. (2015). Evidence-Based Practice. Chicago Elsevier. Ltd. International Encyclopedia of the Social \& Behavioral Sciences, 8(2). dx.doi.org/10.1016/B978-0-08-097086-8.10540-9.

Thoma, A., Eaves F.F. (2015). A Brief History of Evidence-Based Medicine (EBM) and the Contributions of Dr. David Sackett. Aesthetic Surgery Journal, 1-3. doi: 10.1093/asj/sjv130.

Thompson, C. J. (2016). What is Evidence-Based Practice? Retrieved from: https://nursingeducationexpert.com/what-is-evidence-based-practice/

Wilson, R. D., \& Klein, J. D. (2012). Design, Implementation and Evaluation of a Nursing Simulation: a Design and Development Research Study. The Journal of Applied Instructional Design, 2(1), 57-68. 